\title{
Selahattin Çoruh: Turizmde Bir Adanmışlık Öyküsü
}

\author{
Duygu YETGIN \\ Anadolu Üniversitesi \\ Turizm Fakültesi
}

\section{Giriş}

Selahattin Çoruh ile ilgili yazı yazma konusu ilk gündeme geldiğinde hem heyecanlandım hem de şaşırdım. Öyle ki, Çoruh ile maalesef hiç tanışmamış ve ondan hiç ders almamıştım. İtiraf etmeliyim ki, araştırmaya ilk başladığımda bu kadar farklı ve çok yönlü birisi ile karşılaşacağ1$\mathrm{m}$ tahmin etmedim. Çoruh'un her bir çalışması beni biraz daha şaşırtmış ve etkilemişti. Bu nedenle daha derin araştırmaya başladım. "Türkiye Turizmi Sözlü Tarih Projesi" kapsamında yapılan görüşmelerdeki anılarda yer alması beni doğru kişilere de yönlendirdi. Kendisini bizzat tanıyan kişilerle de görüşme fırsatı buldum. Üniversitelerde yıllarca ders kitabı olarak okutulan kitaplarını ve yazdığı dergileri de satın alarak Çoruh'u daha iyi anlamaya çalıştım. Artık araştırmayı bir kenara koymalı ve yazmalıydım. Bu yazıda turizmi hiç tanımayan bir Türkiye'de birçok turizm kitabının yazarı, eğitimci, halkbilim araştırmacısı, turizm duayeni ve bürokrat yönleriyle de bilinen Selahattin Çoruh'un, mesleki yaşamı, turizm eğitimine katkıları ve seçilmiş eserlerinin yanı sıra meslektaşları ve öğrencilerinin hatıralarındaki Selahattin Çoruh'u da anlatmaya çalışacağım.

\section{MESLEKI YAŞAMI}

Selahattin Çoruh, Artvin/Hopa'da dünyaya gelir (1903). Borçka İlk Erkek Mektepte başmuallim olarak göreve başlar (1923). Darülmuallim¹ mezunu olduğu anlaşılan Çoruh, uzun yıllar Ankara İlktedrisat ${ }^{2}$ Müffetişi olarak görev yapar.

\footnotetext{
${ }^{1}$ Darülmuallim: Öğretmen yetiştiren bu okullarda dini derslerin yanı sıra dil dersleri, Tarih, Coğrafya, Hesap, Hat, Türkçe, Matematik ve Kimya gibi modern çağa uygun dersler de verilmektedir.

2 İlktedrisat: İlköğretim
}

Bu sırada Çoruh'un, "Okullarda Dramatizasyon" (1943) adlı kitabı yayınlanır ve çok ilgi görür. Çoruh, kitabın büyük ilgi görmesi üzerine yeni ilavelerle genişletilmiş ikinci basımını hazırlayarak yayımlatır (1950). Önsözünde "Okullarda Dramatizasyonun birinci baskısı bir deneme mahiyetinde olmasına rağmen, Milli Eğitim Bakanlığınca takdirle karşılanmış, meslektaşlarımız arasında ilgi uyandırmış ve bazı mesleki fikir dergilerinde takdirkâr yazıların yazılmasına vesile teşkil etmiştir." şeklinde bir yazı yer almaktadır.

Daha sonra Basın-Yayın ve Turizm Genel Müdürlüğü'nde İç Yayın Dairesi'nde göreve başlar (1943). Bu tarihte İkinci Dünya Savaşı sona erer. Avrupa'nın ekonomik durumu kötüdür. Marshall Planı ile Avrupa ülkelerine yardım yapılmaya karar verilir. Sanayi dallarının yanı s1ra turizme de önem verildiği görülünce bu konu incelenmeye başlanır. Basın-Yayın Umum Müdürlüğü bünyesindeki Turizm Dairesi'nin görevi 16 Temmuz 1943 tarihinde yürürlüğe giren "Basın ve Yayın Umum Müdürlüğü Teşkilat, Vazife ve Memurları Hakkında Kanun" ile belirlenir. O tarihte adı Basın ve Yayın Umum Müdürlüğü olan birimin Turizm Daire Müdürü Süreyya Ergün'dür. Ancak o sırada Etüt Heyeti Başkanlığı'nı gerçekleştirir. Süreyya Ergün'den Turizm Dairesi'ni gerçek anlamda kurması istenir. Ergün, işe başlamak için Çoruh ile çalışma şartını koyar. Böylece Çoruh, Turizm Daire müdür muavini olur. Turizm Dairesi'nde iki oda bir daktilo bir memur ve odacı vardır. TÜRSAB dergisine verdiği röportajda Çoruh, o günleri şöyle anlatır:

İstanbul'u bilirim, turistleri de zaman zaman yolda görürüm ama turizmi bilmek başka bir şey. Mecburen vazifeye başladım... İş yok güç

Cilt $29 \bullet$ Sayı $1 \bullet$ Bahar 2018 
yok, ama kitaplar ve raporlar bulup okumaya başladım. Basın Yayın Müdürü'ne gittim ve 'İsviçre, Almanya, Fransa ve İtalya'dan turizmle ilgili kitaplar getirtin' dedim. Beş altı tane kitap yurtdışından geldi ve tercüme edilmesi için gönderdim. Tercüme edilince iyice inceledim, notlar alıp müdürün odasına gittim. 'Turizmi artık öğrendim, ama bu memlekette turizm olmaz. Aşçı, garson, otel, oteli işletecek adam şu yok bu yok' dedim. Haklı bulundum... Müdür Muavini olarak sekiz ay çalıştım, sadece bu işin niçin olmayacağını öğrendim. Hem halk hazır değil hem de ilgili makamlar. Sonunda $\dot{I}_{c ̧} \mathrm{Ba}$ sin Şubesi'ndeki görevime iademi istedim...

Çoruh'un isteği kabul edilir ve İç Yayın Dairesi'ndeki görevine geri döner (1944). Bu dönemde "Aritmetik Öğretimi" (1945), "Sümer Kahramanı Engidu" (1946), "Bir Gezinin Notlarn Ankara'dan Rize'ye" (1948) adlı kitapları yayınlanır. Bunun yanı sıra İlköğretim dergisinde sık sık yazıları yer alır. Turizm konusunun öneminin anlaşılmaya başlamasıyla 25 Mayıs 1948 tarihinde Basın Yayın Umum Müdürlüğ̈̈'nün ismi Basın-Yayın ve Turizm Genel Müdürlüğü olarak değişir. O dönemde Siyasi Tarih Profesörü olan Ahmet Şükrü Esmer 29 Haziran 1949 tarihinde Basın-Yayın ve Turizm Genel Müdürlüğ̈̈'ne atanır. İlk iş olarak Selahattin Çoruh'u çağırarak ona "Selahattin, sen maarifçisin ${ }^{3}$ Turizm Dairesi'nin başına bir adam bul" der. O sirada Turizm Dairesi'nde bir daktilo ve bir de odacı vardır. Hatta o odacının lakabı da çalıştığı Turizm Dairesi'nden dolayı Turist Ahmet'tir. İstenildiği gibi Çoruh, birkaç isim önerse de turizm ile ilgili başarılı bir rapor hazırlaması onun kaderini değiştirir. Selahattin Çoruh, işte tam da hazırladığı bu rapor sayesinde kendi tabiri ile keşfedilir. Basın-Yayın Turizm Genel Müdürlüğü Teşkilat Kanunu'nun yürürlüğe girmesinden (30 Haziran 1949) 45 gün sonra Selahattin Çoruh, Genel Müdür Prof. Dr. Ahmet Şükrü Esmer'in emriyle Başbakanlık Basın-Yayın ve Turizm Genel Müdürlüğü, Turizm Dairesi müdürlüğüne atanır (14 Ağustos 1949). Bu kanunun sekizinci maddesinde "Turizm Dairesi Müdürlüğ̈̈, yurdu yurttaşlara yakından tanıtmak üzere

\footnotetext{
${ }^{3}$ Maarifçi: Öğretim ve eğitim kurum veya kuruluşlarında çalışan kimse
}

gerekli imkânları hazırlar, yabancılarm yurttaki tabiat güzelliklerini sanat eserlerini görmelerini kolaylaştzracak her türlü tedbirleri alır ve bu alandaki özel teşebbüsleri teşvik eder." ifadesi yer alır.

Üç buçuk ay hazırlık yaparlar ve 19 Aralık 1949 tarihinde Birinci Turizm Danışma Kurulu'nda yer alacak üyeleri toplantıya davet ederler. Hazırlanan tasarı, rapor, etütleri tüm üyelere incelemeleri için gönderilir. 22 Aralık 1949 tarihinde Birinci Turizm Danışma Kurulu gerçekleşir. Çoruh, bu toplantıdan sonra turizm konusunda ümitsizliğe kapılsa da kendisini çabuk toplar ve turizm adına yapılacakları belirlemeye devam eder. İkinci Turizm Danışma Kurulu'nda (18 Aralık 1950) valilik ve belediyelerden turizm olanakları hakkında bilgiler toplanmış, konaklama sektörü içine giren mevcut otel, lokanta vb. durumları tespit eden incelemeler yapılmış ve tüm bu bilgiler doğrultusunda raporlar hazırlanmıştır. Turizm bölgelerinin etütleri yapılır, turizm ile ilgili birçok mevzu gözden geçirilir ve tasarılar ve talimatnameler hazırlanır. Bu sırada Turizm Endüstrisini Teşvik Kanunu tasarısı hazırlanarak danışma kurulunun incelemesine sunulur. Üçüncü Turizm Danışma Kurulu (28 Eylül-2 Ekim 1953), 22 Mayıs 1953 tarihinde yürürlüğe giren Turizm Endüstrisi'ni Teşvik Kanunu Danışma Kurulu'nda incelemeye alınır. Seyahat acentesi ve büroları talimatnameleri tartışılır. Dördüncü Turizm Danışma Kurulu (7 Şubat 1955) ve Beşinci Turizm Danışma Kurulu (25 Mayıs 1958) gerçekleştirilir. Turizm Dairesi müdürü olarak Çoruh, bu kurulların hepsinden, ön çalışmaların yapılmasından ve gerekli tüm hazırlıklardan sorumludur.

Birinci Turizm Danışma Kurulu'nda Devletin Üzerine Alacağı İşler Bölümü'nün 8 . Maddesi'nde "Halk için radyo, basın; vesair vasıtalarla devaml turizm bilgi ve terbiyesinin verilmesi" yer alır. Ancak turizm sevgisi ve bilgisinin radyo aracılığıyla kimin tarafından aktarılacağ İkinci Turizm Danışma Kurulu'na kalır (1950). Kurulda bu görevi başarıyla yapacağına inandıkları ismi seçerler: Selâhattin Çoruh.

Çoruh, halka seyahat sevgisini aşılamak, halkta turizm zihniyetinin yerleşmesini sağlamak, ülkenin tarihi ve turizm güzelliklerini, tarihî eserle- 
rin korunması gerektiğini anlatmak ve turizmin zenginliklerini değerlendirebilmek için Ankara Radyosu'nda 1951 yılı başından 1958 yılı sonuna kadar her hafta cuma günü en az 10 dakika "Haftanın Turizm Konuşmaları" programında konuşmalar yapar. Çoruh, bu konuşmaların hazırlıklarını çok titiz bir şekilde gerçekleştirir. Çünkü en ufak bir hata ve yanlışlık yurt ölçüsünde ve dinlenen diğer memleketlerde iyi karşılanmayabilir. Bunun farkındadır. Her konuşmadan önce mutlaka kitaplar, ansiklopediler karıştırır; arkeologlara, tarihçilere, coğrafya profesörlerine, ticaret ve ekonomi bakımından da bilgi sahibi kişilere başvurur. 8 Haziran 1951 tarihli "Haftanın Turizm Konuşmaları" programının konusu Akçakoca'dır. Bu konuşma çok fazla kişiye ulaşır ve bu küçük sahil kasabasına olan ilginin artmasını sağlar (Özkök 1955; Yılmazdoğan 2018):

\begin{abstract}
Akçakoca kıyı ile yüksek dağların bu kıyıya inen eteklerinde şirin bir kasaba. Karadeniz'in kendine has kokusunu Akçakoca'da duyuyoruz... Akçakoca'da bir taşın üzerine oturdum. Karadeniz'in renkli enginliğine, dağların koyu yeşiline, inci gerdanlık gibi kıy1yı saran Akçakoca'ya bakıp hayale daldım.
\end{abstract}

1958 yılı başlarında Türkiye radyolarında yapılan bütün konuşmaların incelenmesi görevi Fuat Adalı'ya verilir. 1958 yılının son aylarında kendisini dinleyen Adalı, Çoruh'u odasına çağırır. O sıralarda Bursa'da kapalı çarşı yangını olmuştur. Yangından bir gün sonra bir iş için Bursa'ya giden Çoruh, radyo konuşması için günün konusu olarak Bursa'yı ve yangını ele alır. İki konuşma hazırlar. Bunlardan ilki İstanbul'dan Bursa'ya gelip gitmenin hizlı, konforlu deniz, kara ve hava ulaştırma araçlarıyla gayet kolaylaştığını ve bu nedenle İstanbulluların yaz aylarını geçirmek için Bursa'yı tercih edebileceklerini söyler. Bunun nedeni olarak da İstanbul'un sayfiye yerlerinin apartmanlarla dolmaya başlamasını ve pahalılaşmasını gösterir. İkinci konuşmasında ise, Bursa ipekçiliğinin tarihçesini açıklarken "rivayet edildiğine göre ipek böcekciliği tohumu, VI. Yüzyıl ortalarına doğru Bizans Imparatoru Justinianus zamanında iki rahip tarafından Çin Türkistan'ından gizlice getirilmiş" diye sözler kullanır. Fuat Adalı, son radyo konuşmasıyla ilgili değerlendirme yapmak için çağırdığını belirterek söze başlar ve ekler:
Dostum, bugünlerde hükümet pahalılıktan bahsedilmesine kızıyor. Neden pahalılık kelimesini iki kere kullandın? Sonra, Kıbrıs meselesi ortada dururken ipek böceği tohumunun Bursa'ya getirilmesi hikâyesini ele alarak Bizans'tan, Bizans İmparatorluğu'ndan, Bizanslı rahiplerden söz ediyorsun? Bunları anlatman doğru değil.

der. Olaylara bu şekilde bakmayan Selahattin Çoruh, bu uyarı karşısında çok rahatsız olur ve "Bugünden itibaren Haftanın Turizm Konuşmastnı yapmayacağım" der ve Adalı'nın başka bir şey söylemesine izin vermeden hızlıca yanından ayrılır. Bir daha da radyo programları yapılmaz.

Basın-Yayın Turizm vekili olan Server Somonoğlu, Türkiye Turizm Bankası kanun taslağı için haftada üç kez Çoruh ile görüşür. Tamamlanan taslaktan sonra bir sıkıntı olduğunu sezen Çoruh'a 12 Şubat 1959 tarihinde Basın Yayın ve Turizm Müdürü'nden bir tebligat gelir. Bu tebligata göre "Tetkik ve İstişare Kurulu" üyeliğine tayin edilir. Bu tebligatın anlamı, çok sevdiği ve bu kadar emek verdiği turizmden koparılmaktır. Bu konuyu konuşmak için 16 Şubat 1959 tarihinde Server Somonoğlu'na gider, ama onun özel kalem müdüründen şehir dişında olduğu yanıtını alır (Çoruh, 1974). Dönemin başbakanı Adnan Menderes ve Somonoğlu'nun da bulunduğu heyet, 17 Şubat 1959 tarihinde Londra'da yapilacak Kıbrıs görüşmelerine katılmak için Ankara Esenboğa Havalimanı'ndan yola çıkar. Bu uçak İngiltere'nin başkenti Londra yakınlarında düşer. Uçakta bulunan sekiz mürettebattan beşi, 16 yolcudan ise dokuzu (Basın-Yayın Turizm vekili Somonoğlu, Anadolu Ajansı Genel Müdürü Şefik Arzık, Başbakanlık Özel Kalem Müdürü Muzaffer Ersü) hayatını kaybederken Başbakan Adnan Menderes kazadan hafif yaralanarak sağ kurtulur. Selahattin Çoruh, bu duydukları karşısında çok üzülür. Ama sözleri de yarım kalır...

Tetkik ve İstişare Kurulu'nda geçen bir buçuk yılın sonunda Turizm Dairesi müdürlük görevine geri döner (22 Haziran 1960). O dönemki amirlerin de ona inanması ile önemli çalışmalara imza atar. 20 Aralık 1961 tarihinde görülen lüzum gereği Çoruh'un emekliye ayırıldığını yazan belgeyi teslim alır. Bu onun emekli olmamak için ilk mücadelesidir ve Danıştay aracılı̆̆ıyla dava açar, emekliliğini durdurur. Ancak Turizm Dairesi müdürlüğü görevine dönemez. 
02 Temmuz 1963 tarihinde Turizm ve Tanıtma Bakanlığı kurularak kamu yönetiminde turizm bu tarihten itibaren Bakanlık düzeyine getirilir. 1963 yılı Aralık ayında Turizm ve Tanıtma Bakanlığı merkez kadrosundan Sosyal Turizm Uzmanlığına tayin edilir ve Mersin Turizm ve Tanıtma Bölge Müdürlüğü'ne incelemeler yapmak için görevlendirilir (16 Aralık 1963). Mersin'de bulunduğu 15 gün içerisinde Silifke, Mersin ve Tarsus arasındaki sahil şeridini turizm açısından değerlendirebilmek için geziler yapar. Turizm tesislerini inceler ve halk, belediye ve idari amirleriyle görüşmeler gerçekleştirir. Ankara'ya döndüğünde ise İmar ve İskân Bakanına çıkarak bölge planlamasında konunun istenildiği şekilde işlenmesi için uzmanlar gönderilmesi gerektiğini anlattığı raporları sunar. Bu konu hemen değerlendirilerek çalışmalara başlanır. Turizm ve Tanıtma Bakanlığı'nda uzman müşavir olarak ișe başlar başlamaz (18 Ocak 1964) daha önceki tüm Turizm Danışma Kurulu çalışmalarını organize ettiği için 23-26 Haziran 1964 günleri arasında Altıncı Turizm Danışma Kurulu'nun düzenlenmesi ve işlerin aksaksız yürütülebilmesi için görevlendirilir.

6086 Sayılı Turizm Endüstrisini Teşvik Kanunu'nun tasarı hazırlıkları 1949-1950 yılları arasında yapılır. Bu tasarının kanunlaşması sırasinda karma bir komisyon kanun maddeleri üzerinde görüş alışverişleri gerçekleştirilirken aşağ1da belirtilen birinci madde üzerinde en az 15 dakikalık bir tartışma gerçekleştirilir:

\footnotetext{
Bu kanunun ikinci maddesi gereğince tayin olunan vasıfları taşıyan oteller, moteller, pansiyonlar, gazino ve lokantalar, plajlar, kamplar, eğlence yerleri, spor ve avcilik tesisleri, kaplicalar, istirahat ve tedavi müesseseleri ve bu sayılanlara mümasil tesislerden, mevcut veya yeniden kurulacak olanlar bu kanunun tatbikinde sayılırlar...
}

Çoruh, bu madde konuşulmadan hemen önce telefon geldiği için dışarıya çağrılır ve uzun bir süre telefonda kalır. Geldiğinde hâlâ birinci maddenin düzenlenmiş şeklinde kabulüne denildiğini duyunca muavini Ziya Tuğal'a "Neden bu birinci maddenin müzakeresi uzadı?" diye sorar. Ziya Tuğal'ın bu soru karşısındaki yanıtı şöyledir: "O strada yoktun. Bulunsaydın, komisyon üyelerinin kızdıklarını görürdün. Bu madde için arpa-marpa, odun-modun der gibi otel-motel deyimi kullanılmış. Bu laubaliliğe kızdılar. Bu nedenle, uzun konuşmalar oldu. Motel kelimesi maddeden çıkarıldı." Maddenin müzakeresinde komisyonda bulunmadığına üzülür ve ikinci maddenin müzakeresine geçilmeden 1srarla söz alarak konuşma talebinde bulunur. Kabul edilen konuşmasında aşağıdaki ifadelere yer verir:

\begin{abstract}
...Çeşitli kuruluşlarca üzerinde önemle durulan Kanun Teklifindeki deyimlerde herhangi bir laubalilik bulunmamaktadır. 'Motel' kelimesi arpa-marpa, odun-modun gibi deyimler içinde değildir. Motel kelimesi turizm tesislerinden birinin adıdır. Tanımı ise, motorlu araçlarla seyahat edenlerin yol boylarında kurulmuş olan ve araçlarını park edecek yerlere sahip olan konaklama tesisidir. Sayın komisyon üyeleri; maddenin müzakeresinin yeniden ele alınmasını ve maddeden çıkartılmış olan 'motel' kelimesinin tekrar maddeye konulmasını rica ediyorum.
\end{abstract}

der. Başkan maddeyi gözden geçirir ve "Madde de '..ve bu sayllanlara mümasail tesislerden' denildiğine göre, bu deyim motel kelimesini de içine alır. Bu nedenle, maddenin yeniden müzakeresine lüzum yoktur" diyerek maalesef konuyu kapatır. Motel ile ilgili bu ilginç durum ise, Cumhuriyet Gazetesi yazarı Hamdi Varoğlu imzasıyla fıkra haline bile dönüştürülür.

Türkiye Turing ve Otomobil Kurumu'nun ${ }^{4}$ kurucusu Reşit Saffet Atabinen ile ilk kez tanıştığında onun entelektüel birikiminden etkilenir (1947). Atabinen'e olan saygısı I. Turizm Danışma Kurulu'nda yaptığ daha da artar (1949). Hatta onu bir "turizm akrabası" ve "turizm yakını" olarak görür. Çoğu zaman çevresine turizm alanına olan sevgisinde onun da payı olduğunu anlatır. Atabinen'in sohbetleri Çoruh için yararl, esprili ve kişileri yetiştiren tarzdadır. Bu nedenle, onunla her fırsatta uzun uzun sohbet eder (Çoruh 1965). Türkiye Turing ve Otomobil Kurumu Ocak-Nisan 1965 Belleteni'nde Reşit Saffet Atabinen'in vefat1nın ardından yazı kaleme alarak son cümlesinde onun her zaman hatırlanması gerektiğini yazar:

\footnotetext{
${ }^{4}$ Bu kurum, 1923 yılında "Türk Seyyahin Cemiyeti", 1926 yılında "Türkiye Turing Klubü", 1930 yılından itibaren ise "Türkiye Turing ve Otomobil Kurumu" adlarını almıştır.
} 
... Türkiye Turing ve Otomobil Kurumu'nun kurucusu olarak Türk turizmine büyük hizmetlerde bulunmuş olan Reşit Saffet Atabinen'in yıllık toplantılarda, her zaman rahmetle anılmasinın, sayg1 ve sevgi ile hatırlanmasını kurum büyüklerince gelenek haline getirilmesini gönülden dilerim.

Çoruh, Turizm Bankası'nın kuruluşunda da aktif rol alır. Özdemir, Türk Turizm Tarihinde Bir Büyük Usta: Selahattin Çoruh başlıklı çalışmasında bu konuya geniş yer ayırmaktadır (Özdemir 2017). Çoruh, Ankara'da 1954 yılında faaliyete geçen Bulvar Palas Oteli'nin kurulmasında da etkili olur. 13 Mayıs 1953 tarihinde kabul edilen, 22 Mayıs 1953 tarihinde yürürlüğe giren 6086 sayılı Turizm Endüstrisini Teşvik Kanunu'nun 30. maddesine göre işletmeler 50 milyon liralık bir kredi fonu alabilmektedir. Bu karara göre özel teşebbüsün turizm alanında gerçekleştireceği inşaat, cihaz ve donatım yatırımlarının yüzde ellisi kadar kredi kullanabilecektir (Çoruh 1967). O tarihte Basın-Yayın ve Turizm Genel Müdürlüğü Turizm Dairesi müdürü olan Çoruh, Bulvar Palas Oteli'nin kurucuları olan Ahmet Gültan ile Haydar Ertan'ın, inşaatı yavaş süren iş hanlarını otele dönüştürmelerini tavsiye eder ve bunun için Turizm Endüstrisi Teşvik Kanunu'ndan yararlanarak kredi alabileceklerini söyler (Yılmaz 2018). Bu durum Hasan Gültan'ın hafızasında şu şekilde yer etmiştir:

Babamlara 'siz burayı iş hanı yapmayın. Bakın elimizde şu anda dış kaynaklı çok iyi turizm kredileri var. Burayı otele çevirin. Size bu imkânları sağlayalım' diye bir öneride bulunmuş.

Böylece meşhur Bulvar Palas Oteli, Ahmet Gültan ile Haydar Ertan'ın ortak kararıyla iş hanından otel inşaatına dönüştürülür ve 1954 yılında inşaat biter. Çoruh, müdürlüğü sırasında Türkiye'nin birçok yerine geziler gerçekleştirir. Bu geziler onda, tarihi ve kültürü bakımından dünyaya 1şık olmuş olan bu ülkenin doğru propaganda ve tanıtım çalışmaları ile turizmde çok başarılı olunacağı inancını artırır. Gezi esnasında turizm açısından gerçekleştirdiği inceleme yazılarını rapor halinde Basın-Yayın ve Turizm Genel Müdürlüğ̈̈'nde sunar. Bu raporlar Bursa'nın Turizm Meseleleri (1956), Aydın ve Denizli'nin Turizm Meseleleri (1957), Erzurum'un Turizm Meseleleri (1957) adlı kitaplara dönüştürülür.
Örneğin, Amasra'ya Turizm Dairesi Müdürü iken giden Çoruh, Başvekâlet Basın-Yayın ve Turizm Genel Müdürlüğ̈̈'ne sunduğu uzun raporda Amasra üzerinde önemle durur (1954):

\begin{abstract}
Tarihi zenginlik günlerinin hatıraları içinde bugün balıkçılık ve meyvecilik ile geçinen halkın görgü, nezâket bakımından asaletleri örnek düzeydedir. (...) Plajda yüzlerce kadın ve erkek vardı. Bunlar başka şehir ve kasabalardan gelmişlerdi. Kasaba içinde şortla kadınlar, kızlar dolaşıyordu. Kimse rahatsız etmiyordu. Gece yarısı güzel bir İtalyan kızının tek başına otele döndüğünü gördüm.
\end{abstract}

Türkiye Turing ve Otomobil Kurumu'nun 19571958 yılı toplantısında, her yıl turizm ile ilgili başarılı bir makaleye ödül verilmesi konusu gündeme gelir ve 1957 yılındaki ödül turizm alanındaki yazıları ile tanınan ve belli başlı illerin turizm konusundaki ihtiyaçlarını ayrıntılı raporlayan Çoruh'a verilir (Evcin 2016: 122).

Artvin Turizm ve Tanıtma Derneği, 1965 yılında Ankara'da faaliyete geçer. Çoruh ise, bu derneğin ilk başkanı olarak seçilir. Artvin ili ve ilçelerinin yakın tarihinde yaşanmış savaşlar, göçler, işgaller, kara günler ve Artvin'in ana vatana kavuşmasını sağlayan girişimlerin toplandı ğ 1 "Artvin ve çevresi 1828-1921 savaşları" adlı kitabın önsözünü yazar ve hemşerilerinin kurtuluş yıldönümlerini kutlar.

TÜRSAB dergisinde vefatından iki yıl önce (1985) bir röportajı gerçekleştirilir. "Bostanci'da büyük bir apartmanın ikinci katına çıkıyoruz. 40 yıl öncesinden bugüne sürekli olarak turizm için çalışmış, birçok doğruyu ilk kez söylemiş bir insanla randevumuz var. 82 yaşında bir delikanlı çıkıyor karşımıza.." diye devam eden yazıda Çoruh'un turizmle tanışma öyküsünü yer alır. Bu yazının başlığı "Bir turizm mücahiti Selahattin Çoruh"tur. Araştırmacıya verdiği kartvizitte "Başbakanlık, Basın-Yayın ve Turizm Genel Müdürlüğü, Turizm Dairesi Müdürlüğü'nden, Turizm ve Tanıtma Bakanlığı Turizm Uzman Müşavirliği'nden Emekli-Yazar" ifadeleri bulunur (TÜRSAB 1986).

Ömer Adıgüzel, Ĕ̆itimde Yaratıcı Drama adlı kitabının, Türkiye'de eğitimde yaratıcı dramanın gelişimi bölümünde Yaratıcı Dramanın Türkiye'deki öncülerinde Çoruh'a ve eserlerine geniş yer verir (Adıgüzel, 2017). Adıgüzel diğer çalış- 
malarında da Çoruh'un drama ile ilgili çalışmalarına mutlaka yer verir. Mehmet Özdemir, Selahattin Çoruh ile Ağustos 1984 tarihinde tanışır. "Türk Turizm Tarihi ve T.C. Turizm Bankası A.Ş'nin Tarihçesi" üzerine uzun bir görüşme yaparlar. Mehmet Özdemir'e göre, Çoruh'un hafızası son derece kuvvetli, olaylara vakıftır (Özdemir 2017).

\section{SEÇiLMiş ESERLERI}

Selahattin Çoruh, bir rastlantı sonucu turizmci olsa da tam bir turizm sevdalısı haline alır. Turizme dair birçok eserleri olan Çoruh, aslen pedagog öğretmendir, bu nedenle, çok farklı konularda makaleler ve kitaplar da kaleme alır. "Okullarda Dramatizasyon" (1943 ve 1950), "Aritmetik Öğretimi" (1945), "Sümer Kahramanı Engidu" (1946), "Ankara'dan Rize'ye" (1948) gibi seyahat notlarının da bulunduğu geniş bir yelpazede kitapları bulunur. 1939 ve 1966 yılları arasında yayın faaliyetini sürdüren İlköğretim Dergisi'nde 1947 yılına kadar sık sık yazıları yer alır. Kızılcahamam'da 29 adet köy okulu kurulması, planları ve diğer tüm çalışmalar için görevlendirilen Çoruh, bu dönemi ayrıntıları ile yazar ve bazı okulların inşaat fotoğraflarına da yer verir (Çoruh 1940).

1 Ağustos 1947 tarihindeki İlköğretim dergisindeki makalenin adı ise "Okul Çağındaki Çocuklar İçin Çocuk Edebiyatı" dır. Bu makalesinde gelişim psikolojisine olan hâkimiyeti şapka çıkartacak derecededir (Çoruh 1947). Çoruh, Turizm Bilgisi adlı kitabını bazı resmi ve hususi talepleri karşılamak için Basın- Yayın ve Turizm Genel Müdürlüğü adına kaleme alır (1952). Kitapların bir nüshasını önemli köşe yazarlarına gönderir. Aşağıda belirtilen gazetelerde adı geçen köşe yazarları Çoruh'tan, dikkatlice okudukları her bir cümleden anlaşılan Turizm Bilgisi adlı kitaptan ve aşina olmadıkları turizmden uzun uzun bahsederler:

(1) Cumhuriyet Gazetesi: 30 Ağustos 1952 - Turizm ve Türkiye turizmi adlı eser - Hüsnü Sadık Durakal

(2) Vatan Gazetesi: 29 Eylül 1952 - Kör Kadı - Devede Tüy - Sadun G. Savcı.

(3) Akşam Gazetesi: 30 Eylül 1952 - Akşamdan Akşama - Turizmin iki hassas noktası - Va-Nü.
(4) Hürses: 1 Ekim 1952 - Şeytanın Gör dedikleri Turizm Bilgisi - Çetin Altan

(5) Yeni İstanbul: 6 Ekim 1952 - Gördükleriniz Parasızlıktan mı? -

(6) Cumhuriyet: 7 Ekim 1952 - Hem Nalına Hem Mihına - Turizme Dair - Abidin Daver.

Memleketimiz uzun müddet turizme karşı kayıtsız kaldiktan sonra nihayet bu işin ehemmiyetini kavramış... Önümde BYTGM Turizm Dairesi Müdürü Selahattin Çoruh'un Turizm Bilgisi adl eseri bulunuyor. Bu faydalı kitap bize turizm hakkında bildiğimiz ve bilmediğimiz birçok şeyi öğrettiği gibi bu mühim mevzuda memlekette yapılan işlerden ve neşredilen kanunlardan da bahsediyor. (Abidin Daver, 7 Ekim 1952).

(7) Cumhuriyet: 11 Ekim 1952 - Hem Nalına Hem Mıhına - Darısı Başımıza - Abidin Daver.

(8) Son Saat: 10 Ekim 1952 - Estiği Gibi - Turizm Bilgisi Adlı Kitap - Zeria Karadeniz.

(9) Hürriyet: 02 Kasım 1952 - Turistlik Neşriyat Ahmet İhsan

(10) Zafer: 03 Kasım 1952 - Turizm Meselesi -Haluk Ökeren

(11) Siyasi İlimler Mecmuast: Say1: 260 - Turizm Bilgisi - Hasan Refik Ertuğ.

"Ekonomik Dayanağımız Turizm" (1962) adlı kitabında ülkenin iktisadi durumu, turizm ekonomisi ve sanayisi, turizmde teşkilatlanmalar, turizm danışma kurulları, turizm suçları, turizm sanayiinin teşvik ve himayesi gibi başlıklar yer alır. Çoruh'un bu kitabının önsözünde kitabın okunmasını ve okunduktan sonra eleştirilmesi gerektiğini belirten bir yazısı vardır:

\footnotetext{
Dileğim, bu kitapçığı her aydın kimsenin okumasını istiyorum. Okuduktan sonra görüşlerini ve tenkidlerini bildirirse beni çok sevindirir. Böyle bir bildiri bir iki satırla da olabilir. En acı tenkidler bekliyorum yeter ki bu kitapçık okunsun. Turizm konusunun memleket ölçüsünde bir dava olmasını istiyorum.
}

26 Kasım 1960 yılında eğitim müşaviri olan Dr. Anthony R. Lanza, "Turizm Bilgisi" adlı kitabı tercümanlar aracılığıyla inceler. Türkiye'de turizmin önemini anlayan çok az insandan birisi olarak Çoruh'u gösterir ve kitabın bir ilk olması 
nedeniyle emsalsiz olarak nitelendirir. Bu yazı, “Turizm Bilgisi ve Turizm Meselelerimiz (1963) adlı kitabın önsözünde bulunmaktadır. Bu kitapta turizmin gelişimi, turizm endüstrisi, turizmde propaganda, turizm meslek ve teknik öğretimi, sosyal, gençlik ve öğrenci turizmi, Türk turizmi için bugüne kadar gerçekleştirilen çalışmalar gibi bölümler yer alır.

"Genel Turizm Bilgisi" (1967), "Turizm Bilgisi ve Turizm Meselelerimiz" (1963) kitabının geliştirilmiş ve güncellenmiş bir halidir. Bu kitap daha çok eğitim-öğretim kurumları için hazırlanır. Genel turizm kitapları "İnsan, doğuştan hareketli ve gezgindir." veya "İnsan, yaratılışında hareketlidir." gibi cümleler ile başlar.

Türk turizm tarihine tanıklık etmiş hatta başrolde yer almış birisi olan Çoruh, "Turizm Çalışmalarımızın Geçmiş Günleri" başlıklı (1974) kitabında; turizm ile ilgili tüm çalışmaların ayrıntısına yer verir. Aynı zamanda bu kitap, turizm eğitim kurumlarının öykülerini, Turizm Bankası' nı, turizm derslerinin yaygınlaşmasını, Turizm Danışma Kurulu'nun ilk toplantısından altıncı toplantısına kadar olan kısmı, Türkiye'deki ilk turizm çalışmalarını, turizm ile ilgili hukuki mevzuatı gibi turizme dair birçok konuları içerir.

\section{TURIZM EĞiTIMINE KATKILARI}

Köy okulundan liseler ve öğretmen okullarına kadar tüm okullarda turizm dersleri verilmesi için 1951 yılında Milli Eğitim Bakanlığı yetkilileri ve üniversite Profesörleri ile yapılan çalışmalarda bulunur. Bu derslere titiz bir şekilde kaynak kitaplar hazırlar. Milli Eğitim Bakanlığı Talim ve Terbiye Dairesi'nde kurulan komisyonun çalışmalarına katılır.

Gümrük muayene ve muhafaza memurları kurslarında, Kayseri ve Ankara'daki Polis Enstitüsü ve kolejlerinde, Jandarma subay ve astsubay okullarında, Kaymakamlık kurslarında, Ankara Polis Enstitüsü'nde beşer saatlik turizm dersleri verir. Bunların yanı sıra Milli Güvenlik Akademisi'nin isteği üzerine İzmir Hava Harp Okulu, İstanbul Deniz Harp Okulu ve İstanbul Harp Akademisi'nde turizm ile ilgili konferanslar verir (Çoruh 1974). Ankara Otelcilik Okulu'nda turizm dersleri verir.
Ankara'da 16 Ocak 1956 tarihinde "Sekreterlik Öğretmeni Yetiştirme Merkezi” ve aynı yıl "Ticaret Öğretmen Okulu" adı altında öğretim süresi üç yıl olarak Ankara Olgunlaşma Enstitüsü'nün bir bölümünde öğretime başlar. Daha sonra 1959 yılında Ticaret Yüksek Öğretmen Okulu olarak ismi değişerek Maltepe'de bulunan binaya taş1nır (Yetgin 2018). Çoruh, bu okulun yüksek ihtisas okulu olması için Mesleki ve Teknik Öğretim müsteşarı dâhil birçok kişiyle görüşme yaptıktan sonra 26 Mart 1965 tarihinde turizmin ülkedeki önemini vurgulayan, üst kademe kalifiyeli çal1şanların yetiştirilmesi ve turizm öğretmenlerine olan ihtiyaca değindiği ve Ankara'daki Ticaret Yüksek Öğretmen Okulu'nun bu ihtiyacı karşılayacak kadroya, okul, donanıma sahip olduğunu belirten bir rapor hazırlar (Çoruh 1974). Bu yazı üzerine bu okul dört yıllık Ticaret ve Turizm Yüksek Öğretmen Okulu'na dönüştürülür (19651966). (1) İşletme ve Muhasebe, (2) Büro İdaresiSekreterlik (3) Turizm İşletme ve İdarecisi olmak üzere üç ayrı bölüme ayrılır. İlk iki sene derslerin ortak işlendiği bu okulda üçüncü sınıfın başlangıcına denk gelen Eylül veya Ekim aylarında öğrencilere hangi konuda uzmanlaşmak istedikleri sorulur ve dilekçe ile uzmanlaşmak istedikleri bu üç bölümden birini okulun yönetimine bildirmeleri istenir. 1956 yılındaki açılışından bugüne kadar ülkeye sayısız orta dereceli ticaret ve turizm meslek liselerine meslek öğretmenleri, öğretim elemanları, yazarlar, siyaset adamları ve ticaret ve turizm sektörü çalışanları yetiştirir. Bu ve bunun gibi nedenlerden dolayı ticaret ve turizm eğitimi konusunda her zaman öncü olmuş bu okul tarihe geçer (Yetgin 2018).

Ticaret ve Turizm Yüksek Öğretim Okulu'nda dört şube halinde bulunan tüm birinci sınıflara Genel Turizm Bilgisi; Turizm İşletme ve İdarecisi bölümlerinin üçüncü sınıflarına Turizm Coğrafyası; Turizm İşletme ve İdarecisi bölümlerinin ve Büro İdaresi ve Sekreterlik bölümlerinin dördüncü sinıflarına Propaganda, Reklam ve Halkla İlişkiler derslerini 1970 Şubat ayına kadar verir. Bu da haftada 10 saat ders demektir. Hatta 1968-1969 ders yılında 19 erkek, 27 kız olan son sınıf Turizm ve Büro İdaresi Bölümü öğrencileriyle görevli öğretmen Seher Özdoğan'ın de katı- 
lımıyla 20 Mayıs günü Ankara'dan otobüsle yola çıkarlar. Afyon, Uşak, Manisa, İzmir, Bergama, Efes, Aydın, Didim, Miletos, Pamukkale, Side, Manavgat, Silifke ve Gözlü Devlet Çiftliğinde inceleme, araştırma gezisi yaparak 27 Mayıs akşamı Ankara'ya dönerler. Bu uzun gezi sonrası asla yorgunluk bile hissetmezler (Çoruh 1974).

Öğrencileri Ankara Palas Oteli'ne götürür, uygulamalı eğitimlere önem verir. $O$ dönem adı Ankara Arkeoloji Müzesi olan Anadolu Medeniyetleri Müzesi'ne incelemelerde bulunmak için geziler organize eder. Ticaret ve Turizm Yüksek Öğretim Okulu'nda Turizm dersleri grup başkanı olarak görev yapar. Otel sayısının çok sınırlı olduğu bu dönemlerde sektör ile iyi ilişkileri sayesinde öğrencilere staj yerleri ayarlar. Ancak üçüncü kez emeklilik ile ilgili tebligat geldiği için hiç istemese de öğretmenliği bırakır (1970). Emekli olan kişilerin resmi dairelerde çalışmasını engelleyen bir madde kanunlaşmıştır. Aslında yapacak ve anlatacak o kadar şeyi vardır ki... O da bu bilgileri yazıya döker. TÜRSAB yayınları, İller ve Belediyeler Dergisi, Türkiye İktisat Gazetesi, Türkiye ve Dünya'da Turizm ve Turizm Mecmua gibi dergilerde uzun bir süre yazıları yayınlanmaya devam eder.

\section{MESLEKTAŞLARI VE ÖĞRENCILERI GÖZÜYLE}

"Türkiye Turizm Tarihi" çalışması sayesinde o kadar değerli kişilerle tanıştık ki saymakla bitmez. Bu görüşmelerden biri de rahmetli Prof. Dr. Hasan Olalı ile yapılan sözlü tarih görüşmesidir (2013). Görüşme sırasında, Hasan Olalı'ya turizmin öncüleri olarak gördüğü kişilerin kimler olduğu sorusu sorulunca, Olalı bir an bile duraksamadan Selahattin Çoruh'un ismini verir. Turizm açısından değerli bir insan olarak gördüğü Çoruh'un Basın-Yayın ve Turizm Genel Müdürlüğünde çalıştığı için işin bürokratik ve pratik yönlerine hâkim olduğunu böylece turizm alanında birçok başarılı kaynak kitap yazdığını anlatır.

Turizm Bakanlığı, Turizm Eğitimi Genel Müdürlüğü'nde 1964 yılından 2004 yılına kadar çalışan Müzeyyen Acır, ilk işe başladığında Turizm Bakanlarına deneyimleri, bilgi birikimleri ile aktif hizmet sunan bakanlık müşavirlerinden ikisinin yanında görevlendirilir. Bu müşavirlerden birisinin Çoruh olduğunu söyler ve onunla ilgili anılarından şu şekilde bahseder:

Turizm Bakanlığı'nı özellikle beş bölümde değerlendirerek vermek istiyorum. Birinci dönem benim için 1953 ve 1963 yılları arasındaki bilinçlendirme ve kuruluş aşamalarıdır, yapılandırma aşamasıdır ki bu dönemde birlikte çalıştı̆̆ım ilk amirlerimden bir anekdot vereyim size. Bütçe konuşmaları sırasında Basın Yayın Turizm Dairesi Müdürü rahmetli Sayın Selahattin Çoruh, turizmi anlatırken milletvekilleri arasindan, 'turizm nedir? komünizm, kapitalizm gibi bir ideoloji midir' gibi sorulara muhatap olduğunu anlatmıştı.

1965 yılında dört yıllık Ticaret ve Turizm Yüksek Öğretmen Okulu'na geçiş sürecindeki ilk öğrenciler olan Erdal Çetinkaya ve emekli Ticaret Meslek Lisesi öğretmeni Safiye Çetinkaya'nın öğrencilik yılları, okul ile ilgili izlenimleri ve deneyimlerine başvurdum. İlk olarak Erdal Çetinkaya ile sözlü tarih görüşmesi yaptığımda Çoruh'un Ticaret Turizm Yüksek Öğretmen Okulu'na katk1larından ve ona olan minnettarlığından bahsetti:
Bu okulun Ticaret Turizmin turizm ilavesiyle yeni- den açılmasına sebep olan kişi Selahattin Çoruh'tur. Birinci sınıfta bize turizmi anlatmaya başladı, turizmi öğreten de sevdiren de Selahattin Çoruh'tur. Bizimle gezilere katıldı. Bir turizm sevdalısıydı Selahattin Ço- ruh. Yaşı da o zaman 55-60 yaşında vardı. Selahattin Çoruh'un gayretiyle Ticaret Turizm'de turizm bölü- mü açılmış ve ara elemanı yetiştiren bir bölüm olarak Ticaret Turizm'de turizm bölümü mezun vermeye başlamıştı. Bizim okul mezunları turizm ve otelcilik okullarına öğretmen olarak atandı.

Ticaret ve Turizm Yüksek Öğretmen Okulu'ndan 1968-1969 yılında eğitim hayatına başlayan Dr. Şule Çetin, Turizm İşletme ve İdaresi bölümünden mezun olur (1973). Turizmin babası olarak nitelendirdiği Çoruh'tan şu şekilde bahseder: "Selahattin Çoruh, turizmin babasıdır. Biz onun kitaplarını okuduk, çok sevdiğim bir hocamdı." Ticaret ve Turizm Yüksek Öğretmen Okulu'nun Turizm İşletme ve İdaresi Bölümü'nden mezun olan emekli öğretmen Metin Çetin ise Çoruh'u o kadar güzel ifadeler kullanarak anlattı ki ona olan hayranlığım bir kez daha artar:

Keyifle ders anlatan nüktedan birisiydi. Turizm derslerimizin hepsini o verirdi. Genel Turizm ve Turizm Coğrafyası gibi derslerimize girmişti. Derslerde öğrencileri motive etmesini çok iyi bilirdi. 
Hikâyeleştirerek anlatım yapar ama mutlaka anlattığını o günkü dersin konusuna bağlardı. Turizmin tabana yayılması gerektiğini vurgular ve ülkenin kurtuluşu için turizmin anlaşılması gerektiğini söylerdi. Turizm eğitiminde öncüydü. Çok kaynak kitabı vard1. Bu kitaplardan birinin basımında destek olduğumu hatırlıyorum. Turizmciler ve öğretmenlerin dış görünüşlerine her zaman dikkat etmeleri gerektiğini söyler ve eklerdi.. 'Göz önünde olunan mesleklerde bakım şarttır' derdi. Akademik bir unvanı olmasa da o çok değerli ve unutulmaması gereken bir eğitimcidir. Gezilere bizimle birlikte gelirdi.

1966-1970 yılları arasında Ticaret ve Turizm Yüksek Öğretmen Okulu'nda İşletme ve Muhasebe Bölümü’nde öğrenci olan Safiye Çetinkaya, Çoruh'un "Turizm, altın yumurtlayan tavuktur" deyişini hiç unutamaz. Güler yüzlü ve esprili ders anlatışı ile çok rahat bir şekilde turizmi öğrendiklerini, o kadar zorlu derslerin yanında bu zevkli ve anlaşılır dersin keyifle geçtiğini anımsar. Hatta turizmin tanımını rahatlıkla yapabildiğini ve asla unutmadığını belirtir. Türkiye'nin ilk otelcilik okulu olan Ankara Otelcilik Okulu'ndan 1964 senesinde mezun olan Kaya Gürlersan, Çoruh'un Turizm Coğrafyası dersinde öğrendiklerini hiç unutmaz ve onun bürokrat yönünü de takdir eder:

Selahattin Çoruh, Turizm Coğrafyası dersimizin öğ-
retmeniydi. Turizm Bakanlığı'ndan gelen, dünya
tatlısı bir hocaydı. Selahattin Çoruh'un sözleri hep
aklımda 'Turizmci olacaksanız üç şeyi yapmaya-
caksınız. (1) Hiçbir şekilde o binanın içinde politika
konuşmayacaksınız. (2) Hiçbir şekilde o binanın için-
de din konuşmayacaksınız.(3) Hanımlar her zaman
gençtir, onların yaşını hiç sormayacak, hesaplama-
yacaksınız.' derdi... Selahattin Çoruh Hocam, önem-
li bir bürokrattı. O zamanın şartlarında ileriyi gören
insanlardandı. Benim için çok kıymetli bir insandı,
o ve onun gibi bürokratlar, Türkiye'nin turizmi için
inanılmaz planlar, projeler ve katkılarda bulundular.

Baş öğretmenlikten İç Yayın Dairesi'ndeki görevine, Turizm Dairesi Müdürlüğü'nden Sosyal Turizm Uzmanlığına, Turizm Uzman Müşavirliği'nden Yüksek Öğretmen Okulu'ndaki öğretim elemanlığına kadar bir çok görev üstlenen Selahattin Çoruh, her zaman sevilen say1lan birisi olarak anılarda yer eder. Çalışkanlığı, üretkenliği ve güler yüzlü oluşu onun en bilinen özellikleridir. Daha sonra fikralaşacak kadar komik birçok olaya tanıklık eder. Turizmde müdürler gelir müdürler gider, bakanlar gelir bakanlar gider, ama o bikmadan usanmadan turizmin gelişimi için gezilere katılmaya, raporlar hazırlamaya, seminerler vermeye ve makaleler-kitaplar yazmaya devam eder.

\section{DEĞERLENDIRME VE SONUÇ}

Selahattin Çoruh, çok yönlü, disiplinli bir eğitimcidir. O tüm çalışmalarını uygulamaya çalışır ve bunları da mutlaka derli toplu bir şekilde kaleme alır. Öğretmenliğe başladığı ilk yıllardan itibaren hangi alanda çalışırsa çalışsın mutlaka konusuyla alakalı önemli dergilerde onun yazılarına rastlanılır. Tesadüfen turizmci olan Çoruh, tam bir turizm sevdalısına dönüşür. Yazdığı hiçbir şey boş ya da anlamsız değildir. Yıllar öncesinden bugünlerde yaşanması olası sıkıntılara da değinir. Latince 'Verba volant, scripta manent!' şeklinde yazılan bu atasözü Türkçe 'Söz uçar yazı kalır' anlamına gelmektedir. Çoruh, bu atasözünün belki de en başarılı uygulayıcısı olarak karşımıza çıkar. Emekli olmamak için defalarca dava açsa da sonuncusunu (üçüncüsü) kazanamaz ve maalesef emekli olmak zorunda kalır. Emekli de olsa uzun yıllar dergilerde yazıları yayınlanır. Ülkeye yalnız turizm anlamında değil drama, edebiyat gibi alanlarda da çok önemli değerler bırakan Çoruh, 18 Ocak 1987 tarihinde vefat etmiştir. "Okullarda Dramatizasyon" adlı kitabı ile yaratıc1 drama alanında bir öncü olarak kabul edilen Çoruh'un Türkiye turizm tarihinde hak ettiği yeri alması için hazırlanan bu çalışmayı siz okuyucuların takdirine sundum. Umarım Çoruh, bu dünyaya kırgın olarak veda etmemiştir.

\section{SEÇILMIŞ YAYINLARI}

\section{Kitaplar}

Çoruh, S. (1943). Okullarda Dramatizasyon. (Birinci Baskı) Bursa: Ankara Kitabevi.

Çoruh, S. (1945). Aritmetik Öğretimi. İstanbul: AK-ÜN Basımevi.

Çoruh, S. (1946). Sümer Kahramanı Engidu. Ankara: Akba Kitabevi.

Çoruh, S. (1948). Bir Gezinin Notları Ankara'dan Rize'ye. Ankara: Doğuş Matbaası.

Çoruh, S. (1950). Okullarda Dramatizasyon. (İkinci Baskı). İstanbul: Öğretmen Dergisi Işıl Matbaası.

Çoruh, S. (1952). Turizm ve Türkiye Turizmi. Turizm Bilgisi I. Ankara: Basın Yayın ve Turizm Genel Müdürlüğü.

Çoruh, S. (1952). Turizm Bilgisi. Ankara: Turizm Genel Müdürlüğü. 
Çoruh, S. (1954), Herkes İçin Turizm Bilgisi. Ankara: Doğuş Matbaası.

Çoruh, S. (1955). Turizm Bakımından Memleket Etüdleri. Ankara: Basın Yayın ve Turizm Genel Müdürlüğü.

Çoruh, S. (1956). Bursa'nın Turizm Meseleleri. Ankara: Basın Yayın ve Turizm Genel Müdürlüğü.

Çoruh, S. (1957). Aydın ve Denizli'nin Turizm Meseleleri. Ankara: Yıldız Matbaacılık ve Gazetecilik.

Çoruh, S. (1957). Erzurum'un Turizm Meseleleri. Ankara: Basın Yayın ve Turizm Genel Müdürlüğü.

Çoruh, S. (1958). Turizm ve Propaganda. İstanbul: Türkiye Turing ve Otomobil Kurumu.

Çoruh, S. (1959). Belediyeler ve Turizm. Ankara: Türk Belediyecilik Derneği No:11.

Çoruh, S. (1960). Turizm Bilgi ve Terbiyesi. İstanbul: Türkiye Turing ve Otomobil Kurumu.

Çoruh, S. (1962). Ekonomik Dayanağımız Turizm. İstanbul: İstanbul - Ankara Turistik Otel, Lokanta ve Emsali İşverenler Sendikaları Yayınları: 1.

Çoruh, S. (1963). Turizm Bilgisi ve Turizm Meselelerimiz. Ankara: Türkiye Ticaret Odaları, Sanayi Odaları ve Ticaret Borsaları Birliği Matbaası.

Çoruh, S. (1965), Türkiye'de Turizm. Ankara: Turizm ve Tanıtma Bakanlığı.

Çoruh, S. (1965). Garsonun Temel Kitabı. Ankara: Arkın Kitabevi.

Çoruh, S. (1967). Genel Turizm Bilgisi. Ankara: Güven Matbaası.

Çoruh, S. (1969). Genel Turizm Bilgisi. Ankara: Güven Matbaası.

Çoruh, S. (1969). Propaganda - Reklam - Halkla İlişkiler. Ankara: Güven Matbaası.

Çoruh, S. (1970). Turizm Ekonomisi. Ankara: Güven Matbaası.

Çoruh, S. (1970). Turizm Sanayii ve Ticareti Alanında Çalışanlara - Çalıştırıcılara Çağrı. Ankara: Ankara Turistik Otel Lokanta ve Eğlence Yerleri İşverenler Sendikası.

Çoruh, S. (1971). Sosyal Turizm - İşçi Turizmi. Ankara: Türkiye OLEYİ Sendikası.

Çoruh, S. (1971). Resmi Turizm Kuruluşumuza Yeni Bir Şekil Vermek Zorundayız. Ankara: Ankara Turistik Otel - Lokanta ve Eğlence Yerleri İşverenler Sendikası.

Çoruh, S. (1974). Turizm Çalı̧̧malarımızın Geçmiş Günleri.Ankara: Güven Matbaası.

Çoruh, S. (1983). Turizm Dersi (Lise III). İstanbul: İnk1lâp ve Aka Kitapevleri.

\section{Makaleler}

Çoruh, S. (1940). Kızılcahamam Köylerinde Okul İnşaatı, Il köğretim, 2 (40): 343-345.

Çoruh, S. (1943). Aritmetik öğretiminde hareket ve oyunla çalişma örnekleri, İlköğretim, 7 (135-136): 1797-1798.

Çoruh, S. (1944a). Aritmetik Dersleri: Rakamların Öğretilmesi, Deste Fikrinin Kavratılması, Büyük Rakamların Yazdlrılması, İlköğretim, 8 (145-146): 1915.

Çoruh, S. (1944b). Aritmetik Dersleri, illköğretim, 8 (157-158): 2074-2075.
Çoruh, S. ve Gökçe, M. (1943). Aritmetik, Geometri Derslerinin Ülkü ve İlkeleri, İlköğretim, 7 (129-130): 1730-1731.

Çoruh, S. (1947). Okul Çağındaki Çocuklar İçin Çocuk Edebiyatı, Ilköğretim, 12 (233-234): 3036-3038.

Çoruh, S. (1950). Turizm Teknik Öğretimi, İller ve Belediyeler Dergisi, Temmuz (58): 12-13.

Çoruh, s. (1985). 1949 Yılında Turizm Politikası Arayışları. TÜRSAB Aylık Yayın Organı, Ekim 37.

\section{KAYNAKÇA}

Adıgüzel, Ö. (2017). Eğitimde Yaratıcı Drama. Ankara: Pegem Akademi

Çoruh, S. (1967). Genel Turizm Bilgisi. Ankara: Güven Matbaası.

Çoruh, S. (1947). Okul Çağındaki Çocuklar İçin Çocuk Edebiyat1, Ilköğretim, 12 (233-234): 3036-3038.

Çoruh, S. (1940) Kızılcahamam Köylerinde Okul İnşaatı, Ilköğretim, 2 (40): 343-345.

Çoruh, S. (1974). Turizm Çalışmalarımızın Geçmiş Günleri. Ankara: Güven Matbaası.

Evcin, E. (2016). Basın-Yayın Ve Turizm Genel Müdürlüğü Döneminde Turistik Tanıtım ve Propaganda Faaliyetleri, Atatürk Araştırma Merkezi Dergisi, (94): 95-160.

Özdemir, M. (2017). Türk Turizm Tarihinde Bir Büyük Usta: Selahattin Çoruh, Anatolia: Turizm Araştırmaları Dergisi, 28 (1) :143-152.

Özkök, M. (1955). Akçakoca: Karadeniz Kıyısında Şirin bir Plaj ve Sayfiye Kasabası, Akçakoca: Akçakoca Turizm Derneği Yayınları, Sayı:1.

Yetgin, D. (2018). Gazi Üniversitesi Turizm Fakültesi'nin Kurum Tarihi. İçinde; N. Kozak, (Editör) Dünden Bugüne Türkiye'de Turizm (ss. 603-624). İstanbul: Y1k1lmazlar Basin Yayın.

Yılmaz, A. (2018). Ankara Bulvar Palas Oteli (1954-1993). İçinde; N. Kozak, (Editör) Dünden Bugüne Türkiye'de Turizm (ss. 359-378). İstanbul: Y1kılmazlar Basın Yayın.

Y1lmazdoğan G. (2018). Karadeniz'in Devrik İncisi Akcakoca'da Turizm. İçinde; N. Kozak, (Editör) Dünden Bugüne Türkiye'de Turizm (ss. 35-51). İstanbul: Y1kılmazlar Basin Yayin.

\section{Kaynak Kişiler}

Acır, M. (2014) Müzeyyen Acır (Görüşen: Mune Moğol Sever). İçinde N. Kozak (Editör). Türkiye Turizmi Sözlü Tarih Araștırması Görüşme Metinleri, 9. Cilt (ss. 359-371) İstanbul: Y1kılmaz Basın Yayın.

Çetin, Metin. 10 Mayıs 2018 tarihli telefon görüşmesi (Görüşen: Duygu Yetgin)

Çetin, Ş. (2013) Şule Çetin (Görüşen: Savaş Evren). İçinde N. Kozak (Editör). Türkiye Turizmi Sözlü Tarih Araştırması Görüşme Metinleri, 5. Cilt (ss. 341-352) İstanbul: Y1kılmaz Basın Yayın.

Çetinkaya, E. (2013) Erdal Çetinkaya (Görüşen: Duygu Yetgin) İçinde N. Kozak (Editör). Türkiye Turizmi Sözlü Tarih Araştırması Görüşme Metinleri, 5. Cilt (ss. 437-445) İstanbul: Yıkılmaz Basın Yayın. 
Çetinkaya, Safiye. 10 Mayıs 2018 tarihli telefon görüşmesi. (Görüşen: Duygu Yetgin)

Gültan, H. (2015) Hasan Gültan (Görüşen: Aysel Yılmaz). İçinde N. Kozak (Editör). Türkiye Turizmi Sözlü Tarih Araştırması Görüşme Metinleri, 6. Cilt (ss. 224-232) İstanbul: Yikılmaz Basın Yayın.

Gürlersan, K. (2015). Kaya Gürlersan (Görüşen: Arzu Toker). İçinde N. Kozak (Editör). Türkiye Turizmi Sözlü Tarih Araştırması Görüşme Metinleri, 5. Cilt (ss. 586-611). İstanbul: Yıkılmaz Basın Yayın.
Olalı, H. (2013). Hasan Olalı. (Görüşen: Ece Doğantan). İçinde N. Kozak (Editör). Türkiye Turizmi Sözlü Tarih Araştırması Görüşme Metinleri, 5. Cilt (ss. 25-41). İstanbul: Yıkılmaz Basın Yayın.

Duygu YETGIN, Öğr. Gör. Dr., Anadolu Üniversitesi, Turizm Rehberliği Bölümü, Yunus Emre Kampüsü, 26470, Eskişehir.

E-posta:dyetgin@anadolu.edu.tr

https://orcid.org/0000-0002-9909-4523 